\title{
Hereditary entanglement - the significance of whakapapa and genealogical locatedness in Māori research: A researcher's personal experience
}

Ko Hikurangi te maunga

Ko Rangitaiki te awa

Ko Koura te tangata

Ko Patuheuheu te hapū
Hikurangi is the mountain

Rangitaiki is the river

Koura is the ancestor

Patuheuheu is the hapu

This article explores the idea of hereditary entanglement as a concept for recognising whakapapa and the inseparability of genealogical locatedness within the context of Māori research. This article will look at my hereditary entanglement within the context of doctoral research that I completed at Auckland University of Technology. This article will argue that hereditary entanglement is not only unavoidable for Māori researchers who research aspects of their histories and heritage, but that Māori researchers with these connections are, in fact, the only people that can adequately carry out this type of research.

The term hereditary entanglement as it is used here, is unique and as far as I am able to ascertain, is an original term in the context of whakapapa and genealogical locatedness in Māori research. The idea is that as a Māori researcher, researching aspects of my history and heritage that are directly linked to my whakapapa, I am hereditarily entangled in the research work. In my PhD I declared this entanglement and 
argued that my genealogical context informed not only my research practice but also my perspective as a researcher. Therefore, my whakapapa informed my research practice in dialectical and ongoing ways.

My PhD focussed the potential for Māori prophecy to be used as the basis for hapu development; it was based on a prophecy given to the Patuheuheu hapu in 1886 by the Māori prophet, Te Kooti Arikirangi Te Turuki, when Patuheuheu hapū tragically lost their homeland at Te Houhi to hands of Pākehā fraudster by the name of Harry Burt. My PhD was entitled: Ko au ko Te Umutaoroa, ko Te Umutaoroa ko au: Toward a Patuheuheu hapū development model (Rangiwai, 2015). I descend from the iwi of Ngāi Tūhoe, Ngāti Manawa, Ngāti Whare and Ngāti Porou. I am from the Patuheuheu hapū of Ngāi Tūhoe iwi - this lineage connects me directly to my $\mathrm{PhD}$ research.

The name of the prophecy that Te Kooti gave to Patuheuheu hapu was called Te Umutaoroa which means the slow-cooking earth oven. Hence, the use of the name Te Umutaoroa in the title of my PhD. Te Umutaoroa is a prophetic, utopian discourse which promised Patuheuheu the return of their lost lands and resources and, according to some narratives, the discovery or generation of other resources like diamonds, gold, oil and minerals (Binney, 2001). Healer Rita Tupe recalls some of the things her father, Hieke Tupe (considered to be an expert on Te Umutaoroa), said about Te Umutaoroa:

Our father Hieke talked about how Te Kooti was travelling around different parts of Aotearoa, and he came to this area [Te Houhi], but he stopped at Te Arawa first. There he warned the Te Arawa people and told them to move to higher ground because the eruption of Tarawera was going to happen. But I suppose because they didn't believe in a prophet, or a matakite, they ignored his vision. Te Kooti left Te Arawa and carried on this way over to Te Houhi. 
When Te Kooti arrived at Te Houhi he also asked our people to move to higher ground for protection; and so they did move to higher ground. At that time it was Ngāti Haka, Patuheuheu, Ngāti Whare and Ngāti Manawa - those were the four hapu which stayed there together.

Te Kooti rested by his horse and cart at Te Houhi. While Te Kooti rested, he had a dream about this umu which we now know to be Te Umutaoroa; and he talked about these mauri that were left there. He said "Tao ake nei, tao ake nei, ka haramai taku whanaunga ki te hiki ki Te Umutaoroa" [that his relative will come to uplift the slow-cooking earth oven] (R. Tupe, personal communication, 20 October, 2011).

According to both Hieke Tupe (Binney, 2001, 2007, 2009, 2010; Doherty, 1995) and Robert (Boy) Biddle (Binney, 2001, 2007, 2009, 2010) Te Kooti had his vision in 1886 and named the land on which this event took place, Te Umutaoroa. Robert Biddle states:

Up where the Aniwhenua dam is, now, it used to be dry land before... Te Kooti was there, he slept at this particular pā [Te Houhi], and where he did sleep, he said to them in the morning, 'I had a dream last night: the valley of the Rangitaiki here was just dense fog...' He said, 'I couldn't see through this fog, so the place where I slept, it will be known as Te Umutaoroa'. That's a hangi - it would be perpetually in that form until this person came and uncovered it (Binney, 2009, p. 494).

Tūhoe scholar, Wharehuia Milroy corroborates the existence of Te Umutaoroa in the following way: 
Te Umutaoroa was at Te Houhi; it was a place where Te Kooti visited and while he was at this place there was a lot of fog covering the area at that time. There, at that place, Te Kooti placed eight mauri: mauri atua, mauri whenua, mauri tangata, mauri whakapono, mauri whakaora i ngā iwi, mauri hōhonu, mauri arai atu ingā pakanga, mauri whakahoki ingāiwi. One of the statements that Te Kooti made was about Harry Burt finding only "rotting potatoes" at Te Umutaoroa; that the money he received in exchange for on-selling Te Houhi would be like "a pit of rotting potatoes". There was another prediction: "tao noa, tao noa, tērā ka tae mai te tamaiti māna e huki". This means that there is this umu still "operating" in its cooking state. Now whoever the tamaiti is, I don't know, but that person must appear to make Te Kooti's prediction come true; someone has to come out at some time or other, to prove Te Kooti's prediction right (W. Milroy, personal communication, 6 July, 2012).

In this way, Te Umutaoroa is both a commentary on the reality of land loss at Te Houhi, and a hapu-based prophecy that embodied Patuheuheu's hope for things to come.

As in other parts of the Pacific, Māori in Aotearoa traditionally cooked food using an umu, or earth oven. A pit is dug in the earth, in which a fire is burned for a number of hours to heat stones. Once these stones are hot, food in woven baskets is placed on top, covered in leaves and then soil. After the required cooking time, the soil and leaves are removed and the food is ready to be served. Te Umutaoroa refers to this process of cooking in a metaphorical way and, as the name suggests, this particular umu requires a long cooking time. Te Umutaoroa is something that is going to take a long time to unravel (M. Tupe, personal communication, 20 October, 2011). According to Rita Tupe: 
Te Umutaoroa is an $u m u$, and as we know, an $u m u$ is a cooking pit, where food is cooked underground; it is a hāngi. It is made up like a hāngi; you dig a hole and you burn a fire and heat up stones. 'Tao roa' means 'long cooking.' The hängi is still cooking; it's an umu that still hasn't completely cooked yet (R. Tupe, personal communication, 20 October, 2011).

Within this hangi pit it is said that Te Kooti placed eight mauri stones to be uncovered by a future leader, his child or son, to restore all that the people of Te Houhi had lost (Binney, 2001, 2007, 2009, 2010; Doherty, 1995). Hieke Tupe gave the following meanings of the mauri of Te Umutaoroa:

te mauri atua: the essence of spirituality; the belief in God

te mauri whenua: the life force of the land te mauri tangata: the life force of the people te mauri whakapono: the power of belief, or faith te mauri whakaora i nga iwi: the power to heal the people te mauri hohonu: the mauri [life force] of hidden wealth - minerals, gold, diamonds and oil (perhaps), which lie underground

te mauri arai atu i nga pakanga: the power to return war from this land to other countries te mauri whakahoki i nga iwi: the power to return people to their land (Binney, 2001, p. 158).

The uncovering of these eight stones guarantees the people of Te Houhi spiritual and physical renewal, regeneration, reuniting of people and land, and economic security (Binney, 2001, 2009, 2010). Te Kooti's prophecy promises Patuheuheu the 'cooked sustenance' of life and salvation (Binney, 2001, 2007, 2009, 2010). In 1892 Te Kooti clarified his vision further:

Te kupu ki te Umutaoroa - Te Houhi 
Ka taona e ahau tenei hangi ma taku tamaiti e hura

Tenei mea te hangi, ko nga kai o roto hei ora mo te tangata

The word concerning Te Umutaoroa - Te Houhi

I am preparing this hāngi (earth oven) for my child to unearth.

The food inside this hāngi will be for the salvation of the people (Binney, 2009, p. 494).

To this day Te Umutaoroa remains unfulfilled. It is however, a discourse that is in a constant state of flux, shifting from the past to the present, subjected to discursive modification, shaping the prophecy for the particular contexts in which it is used to inspire and give hope. According to Binney (2007):

Te Umutaoroa has become an unfulfilled questnarrative. It is unfulfilled because the land is lost; indeed, it is now drowned beneath the waters of a hydro-electric dam, built in 1980. Little islands dot the lake where Te Umutaoroa once was. Once again new meanings are being wrought from this changed landscape (p. 154).

The aspirations of Patuheuheu hapu are tied to the promises of Te Umutaoroa and so it is believed that all those who whakapapa to the land at Te Houhi will, in the future, have the enigmatic contents of the $u m u$ revealed to them.

The following whakapapa table was used in my $\mathrm{PhD}$ to express my congenital involvement in my research about Patuheuheu hapū's land loss and the prophecy of $\mathrm{Te}$ Umutaoroa, which, like the lens of a camera, filtered, framed and contextualised the research in certain ways. Genealogically and spiritually, my ancestors have contributed to who I am and as such, they have contributed to my perspective and practise as a researcher. Furthermore, my ancestry was and is connected directly to the subject matter. 
Figure 1: Whakapapa

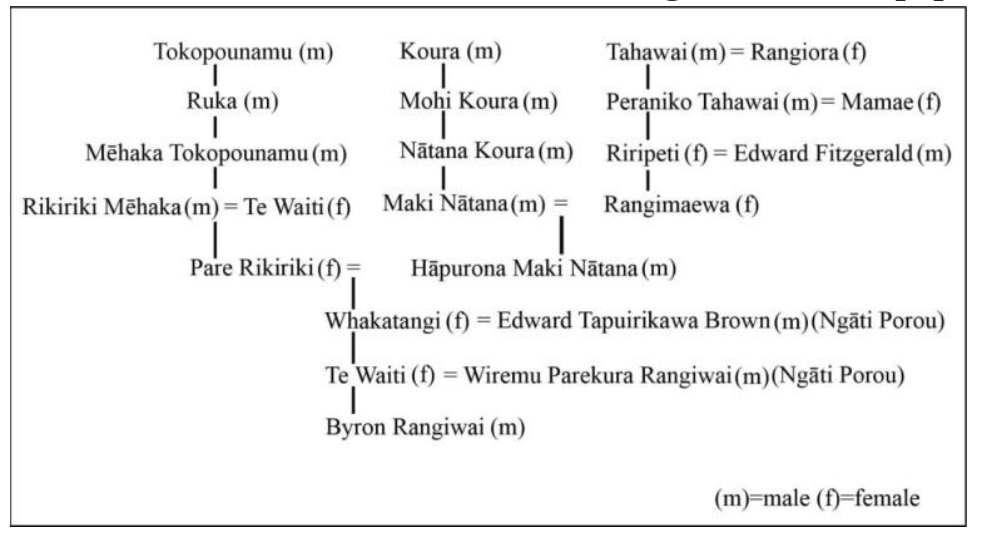

The table shows my descent from Peraniko Tahawai (?-1877), my fourth great-grandfather. Peraniko was the ariki or high chief of Ngāti Manawa from 1864 until his death in November 1877 (Binney, 2009). He was known as "...the renowned leader of the Ngati-Manawa tribe which joined forces with the Royal troops under Captain Gilbert Mair against the Hau Hau uprising of the Te Kooti era" "Haere ki o Koutou Tipuna", 1961, p. 3). According to Crosby (2004), Peraniko had also been a soldier in Gilbert Mair's ${ }^{1}$ pursuit of Te Kooti from 1869 to 1872. In Mair's (1923) account, Reminiscences and Maori Stories, he speaks of his friendship with Peraniko. After Mair (1923) left the Bay of Plenty area, he received word of Peraniko's death, but was unable to travel to Galatea for the tangihanga. Two years after Peraniko's death Mair returned to Galatea and recorded the following account of his experience:

Lifting my eyes to the front of the carved house, imagine my feelings on being confronted with my

1 Gilbert Mair is best known as a soldier, but he was also a land surveyor; land purchase agent; te reo Māori interpreter and tikanga Māori expert, unrivalled amongst Pākehā; and one of the very few Pākehā to lead a Māori fighting unit (Crosby, 2004). 
deceased friend Peraniko, who had been exhumed from the grave wherein he had lain for two years. ${ }^{2}$ The body had been carefully washed; his jet-black hair, which had grown very long, was oiled and ornamented with rare plumes of the huia and white crane. He was seated on a high structure plentifully adorned with choice mats, while his cold hand still grasped the family talisman, a greenstone mere. Death had wrought no change, nor was there the slightest odour. He had always been remarkable during life for his high complexion, rivalling that of a half-caste, and it still appeared perfectly natural, except for slight dark rings under the eyes, which were closed as though asleep. ${ }^{3}$ At his feet were the faithful widow bowed in an agony of grief, and with her were the children. 4

Hatless and with bowed head I stood for nearly three hours, deeply moved by the affecting strains of the tangi (pp. 65-66). 5

2 Both McBurney (2004) and Boast (2008) comment that some scepticism exists around the story of Peraniko's exhumation.

3 According to Wharehuia Milroy (Personal communication, 5 September, 2013) in some areas like Murupara where there is an abundance of pumice in the soil, bodies were sometimes stored and preserved in the ground where the pumice acted as a means of preservation; when a body needed to be resurrected for tangihanga proceedings - which could last for weeks, months or years, depending on the rank of the deceased person - the body was removed from the earth and placed again on the marae. Other methods of tūpāpaku (corpse) preservation included smoking after removing and burying the organs, and storing the body in certain types of tree hollows (W. Milroy, personal communication, 5 September, 2013).

4 I descend from the union of Peraniko and Mamae, through their daughter Riripeti (see Figure 1). Mair (1923) stated that: "Two of their [Peraniko and Mamae] children had been baptized Te Mea and Riripeti (Elizabeth) after my parents" (p. 64). ('Te Mea' is probably a transliteration of 'Mair'.)

5 Mair (1923) noted that after much haka (posture dance) and feasting, he had been asked to join a small group of elders who 
I grew up in the small community of Murupara - the rohe of Ngāti Manawa. The name Peraniko is carried by a number of my close whanaunga. Peraniko's status as ariki of Ngāti Manawa is memorialised through whakapapa, kōrero, waiata and haka. He is also featured as one of the pou inside the meeting house, Apahāpaitaketake, at Rangitahi marae. His significance to my research is not only about my descent from him but also the historical connections that he has to the research itself as his connection to Mair, and Mair's connection to Te Kooti.

The table also shows my relationship to my fifth greatgrandfather, Koura, a Ngāti Rongo and Patuheuheu chief with a close connection to Ngāti Manawa, who lived at Horomanga in the 1830s (Mead \& Phillis, 1982; Waitangi Tribunal, 2002). Local history maintains that it was Koura's responsibility to maintain the mana of Tūhoe in the Te Whaiti, Murupara, Horomanga, Te Houhi and Waiōhau areas. He was heavily involved in the political negotiations surrounding the tatau pounamu, or enduring peace agreement, between Tūhoe and Ngāti Awa which occurred somewhere between the early 1830s (Waitangi Tribunal, 2002) and 1835 (Binney, 2009). Referring to the tatau pounamu, Mead and Phillis (1982) state: "Koura ...is remembered by Ngati Awa and Patuheuheu of Waiōhau and Ngati Manawa of Murupara as the principal man on the Tuhoe side" (p. 241). Te Kooti's famous waiata tohutohu, Kāore te pō nei mōrikarika noa, reminds Tūhoe and Ngāti Awa of that very agreement: "He rongo ka houhia ki a Ngāti Awa" ("A peace made with Ngāti Awa”) (Binney, 2009, p. 269).

This agreement was of great significance because it brought 200 years of inter-tribal conflict to an end (Waitangi Tribunal, 2002). That conflict was symbolised by the bush at Ōhui (Mead \& Phillis, 1982). According to Mead and Phillis (1982):

carried Peraniko away to a temporary burial place, until he was taken to his final resting place. 
...the peace treaty is remembered by the people of the Mataatua region as being between Koura and Hatua (p. 243).

Lesser men could not have cemented the tatau pounamu. ... Koura and Hatua did not fail and as a result their names live on in the memories of the people...

Koura of Ngati Rongo and Patuheuheu representing the Tuhoe side of the bush at Ohui, and Hatua of Ngati Pahipoto representing the Ngati Awa side of the bush. One is symbolised forever by Tawhiuau which can be seen clearly at Galatea and Murupara and the other is symbolised by Putauaki which dominates the land around Kawerau, Te Teko and Whakatane (p. 245).

It was here, beneath the shadow of Tāwhiuau maunga, that Mead (cited in Waitangi Tribunal, 2002) claims that Patuheuheu and Ngāti Haka lived under Koura's leadership. My descent from Koura is highly significant to the topic of my $\mathrm{PhD}$ research. My maternal great-grandfather, Hāpurona MakiNātana left a legacy behind for our whānau that was based on our direct descent from Koura; it is a legacy of strength, fortitude, and resilience. Koura was a powerful leader and so, when someone within the whānau is seen to be a strong person, they are said to have 'shoulders like Koura'. Koura is an ancestor to whom we look to for inspiration as a whānau. He was an extraordinary leader, who is also known to us as a tohunga or healer. A number of our whānau members are healers and claim this gift as a result of their lineage from Koura.

The whakapapa table also shows that I am a third greatgrandson of Mēhaka Tokopounamu (c.1835-1920) who was intimately linked to Patuheuheu and to the Tūhoe hapū of Ngāti Koura and Ngāti Tāwhaki (W. Milroy, 10 September, 2013, 
personal communication). ${ }^{6}$ Mēhaka was also closely connected to Ngāti Manawa and Ngāti Whare. In the mid-nineteenth century Mēhaka Tokopounamu and the older chief, Wi Pātene Tarahanga, were the rangatira of Te Houhi (Binney, 2009). These men led their people in the struggle against colonial oppression and so "[t]heir example of leadership and their determination to right the wrong must not be allowed to rest" (Paul, 1995, p. ii).

6 Reference to Mehaka Tokopounamu as a speaking representative for Ngāti Tāwhaki can be found in Waaka (2001, p. 9). Indeed, Waaka (2001) also states that Ngāti Whare had intermarried into neighbouring Ngāti Tāwhaki (a hapū of Tūhoe), which supports Best's (1902) claim that Ngāti Whare had intermarried into Tūhoe, thus protecting Ngāti Whare from Tūhoe attacks. 
Image 1: Recommendation certificate endorsing Mēhaka Tokopounamu

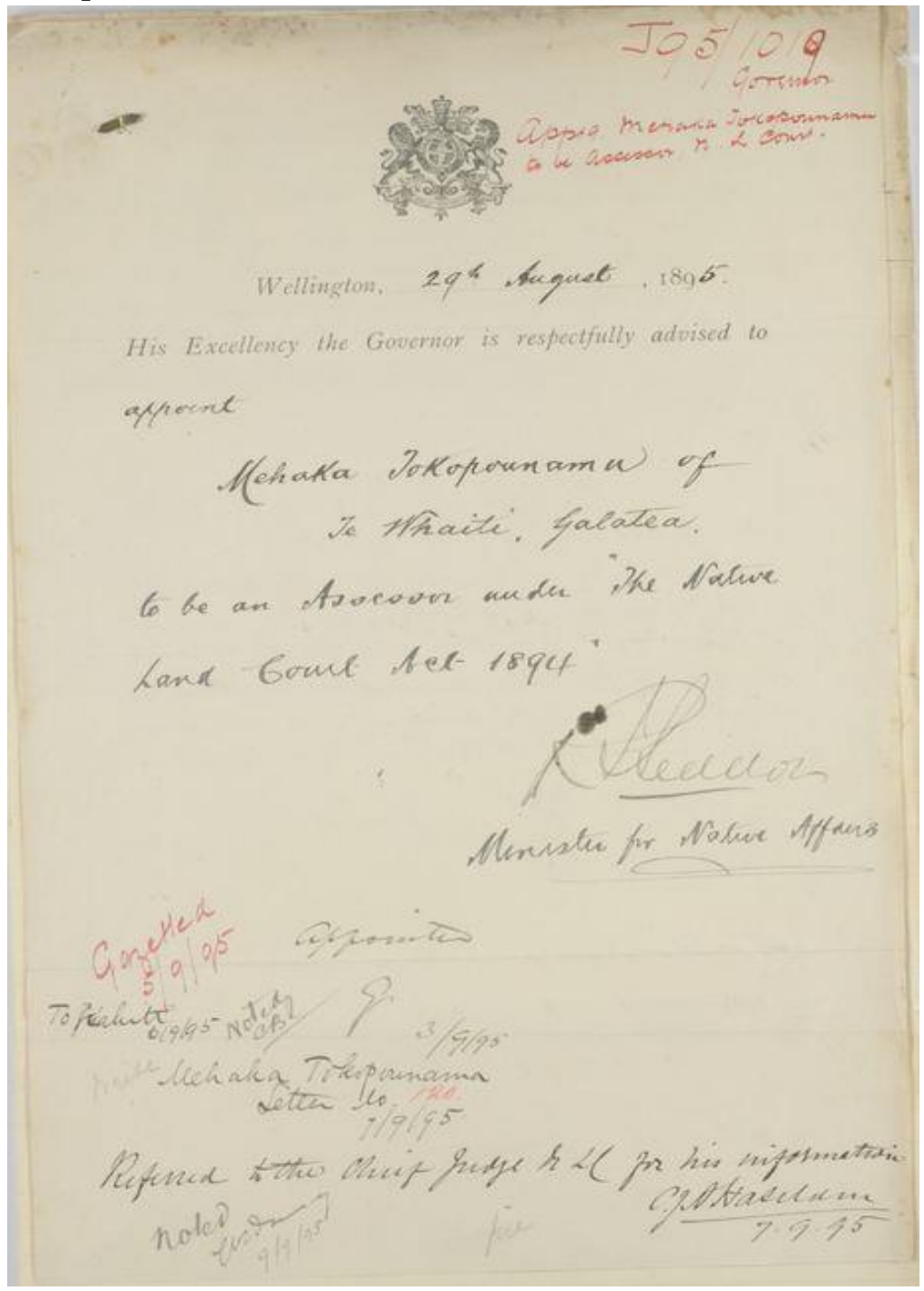

(Archives New Zealand, 2010, p. 182) 
This recommendation certificate recommends the appointment of Mēhaka Tokopounamu as an assessor: "His Excellency the Governor is respectfully advised to appoint Mehaka Tokopounamu of Te Whaiti, Galatea, to be an Assessor under the Native Land Court Act 1894" (Archives New Zealand, 2010a, p. 182). Te Whaiti is the home base of Ngāti Whare and Galatea (Te Houhi/Kuhawaea) was the home base of Patuheuheu, Ngāti Haka and Ngāti Manawa.

Mēhaka's name is very prominent in the historical archives (J. Binney, personal communication, 30 November, 2009) as he was heavily involved in the Te Urewera land issues of the 1890s (W. Milroy, personal communication, 6 July, 2012). In a speech to honour the 2009 Parliamentary launch of Binney's book, Encircled Lands: Te Urewera, 1820-1921, Minister of Treaty of Waitangi Negotiations, Christopher Finlayson stated:

I te tau 1895 i heke mai ètahi rangatira o te Urewera ki te kawe i ngā take whenua ki te whare paremata. Nā Tā Timi Kara te mema paremata i whakatakotongia ngā tono a ngā rangatira o te Urewera i mua i te aroaro o te whare. Ko ētahi o ngā rangatira i taua wa; ko Marunui, ko Harehare, ko Rewi, ko Tokopounamu, ko Mihaere, ko Te Korowhiti, ko Paraki, ko Wharepapa me ètahi atu (Finlayson, 2009, n.p.).

The Minister refers to an event in 1895 where chiefs from Te Urewera travelled to Wellington to take their land issues to Parliament where James Carroll (Timi Kara), member of the House of Representatives, presented the requests of the chiefs before the House. The Minister then names some of the chiefs who were involved and (Mēhaka) Tokopounamu, as a representative of Patuheuheu, is mentioned amongst them. 


\section{Image 2: Deputation of Urewera chiefs to Richard John Seddon, at the Ministerial Residence, Molesworth Street, Wellington}

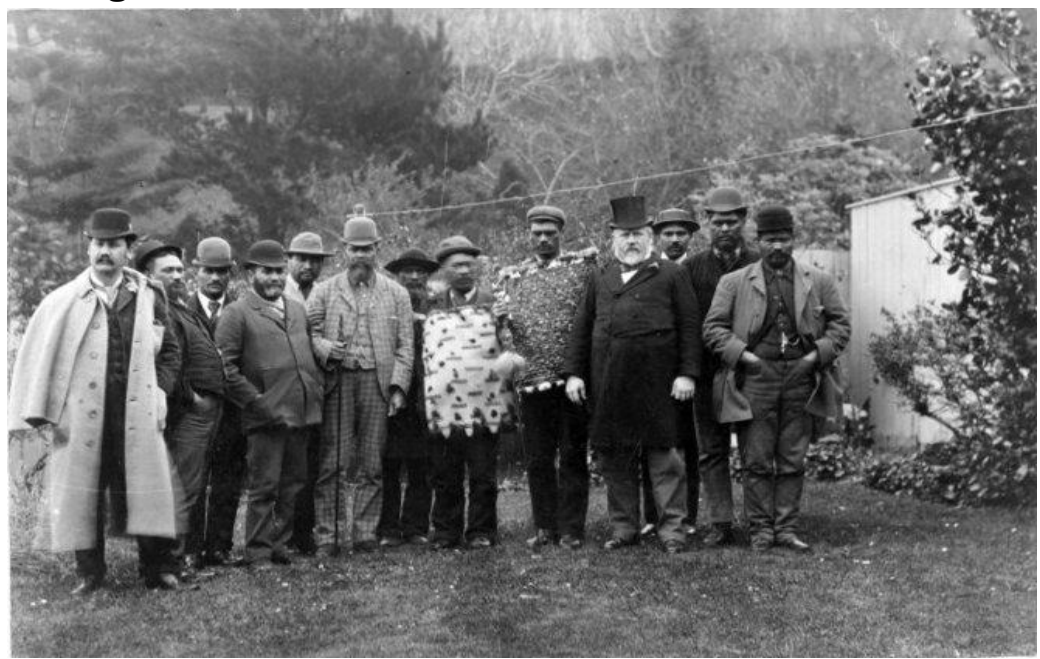

(Seddon family, Alexander Turnbull Library, n.d, 1/2-098554-)

James Carroll (member of the House of Representatives) is on the left. Seddon, wearing a top hat, is fourth from the right. The chiefs in this photograph include: Te Wharekotua; Mēhaka Tokopounamu and Te Korowhiti, both representing Patuheuheu; Harehare Aterea (Atarea) and Te Marunui Rawiri representing Ngāti Manawa; Paraki Tiakiwhare of Ngāti Manunui is in the centre wearing the woven cloak; and Hurae Puketapu from Waikaremoana is at the far right. Mēhaka is yet unidentified in this photograph.

Mēhaka was very much involved in the tribal politics and leadership of his time. According to Wharehuia Milroy: ${ }^{7}$

7 Dr Wharehuia Milroy CNZM, QSO, is a Tūhoe academic who descends from Tūhoe's senior chiefly lines. 
Mēhaka Tokopounamu was associated very closely with my great-grandfather; they were extremely close. They lived together at Ōtenuku. The Rikiriki family, who are descended from Mēhaka Tokopounamu, used to make their appearances at Ōtenuku marae, because Mēhaka shared his time with my great-grandfather Tamarau Waiari, 8 or Te Wharehuia as he was known, on a lot of different tribal issues, where they always supported each other. When I look at the whakapapa, yes I can understand why they did this, because of the proximity to each other in the whakapapa - that's one part of it. But the other part of it is that Mèhaka lived, for quite a period of time, with Tamarau Waiari; they shared a lot of leadership. So Mēhaka was one of the main witnesses to a lot of those Te Urewera land issues of the 1890s and I'm not sure when he died, because my great-grandfather died in 1904, I think Mēhaka may have lasted longer than him. Mēhaka was a central figure in those debates over the land issues; not only that, but Mēhaka came over and lived at Ōtenuku for a long period of time. He was also involved in the Rūātoki meetings as one of the main witnesses for those Rūātoki lands which challenged the Ngāti Rongo claim that substantial areas belonged to the ancestor Rongokārae. Rongokārae was really from Ngāti Awa but he took to wife the daughters of Kuramihirangi and Tahatū-ki-te-ao, Tawhiwhi and Rangimāhanga. Their land interests were the subject of the debates that took place during the course of the Te Urewera Land Commission hearings (personal communication, 6 July, 2012).

8 For more information on Tamarau Waiari see Milroy (1994) and Binney (2008, pp. 12-14). 
Mēhaka left behind a legacy of leadership that flows through his descendants. From a research standpoint, his legacy and direct involvement in the history of the land and experiences from which the topic of my doctoral research emerged meant that the research was contextualised for me, as the researcher, in terms of my whakapapa.

\section{Image 3: Inscription on memorial stone for Mēhaka Tokopounamu, Patuheuheu marae, Waiōhau}

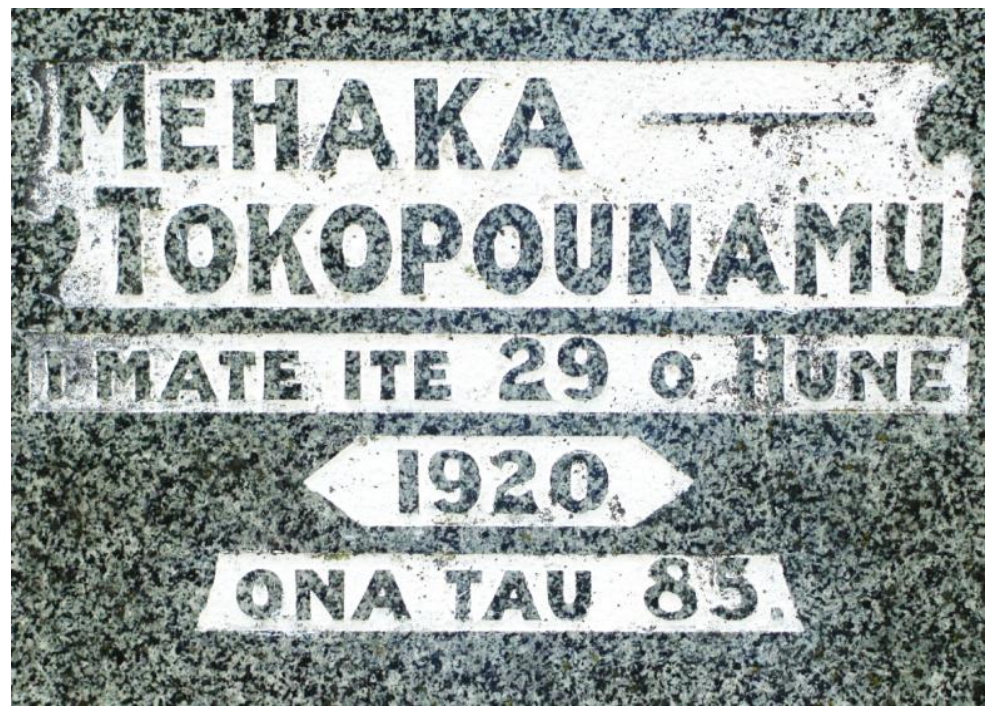

(B. Rangiwai, personal collection)

The inscription states: "Mehaka Tokopounamu died on 29 June 1920 at age 85 "

My great-grandfather, Hāpurona Edward (Ted) Maki Nātana (1921-1994), was a staunch advocate for Patuheuheutanga Patuheuheu culture, customs, values and beliefs. Koro Hāpurona was Patuheuheu on his father's side (with 
connections to other Tūhoe hapū), and Ngāti Manawa and Irish on his mother's side.

\section{Image 4: Memorial plaque for Hāpurona Maki-Nātana (reflecting Tama-ki-Hikurangi wharenui), Patuheuheu marae, Waiōhau}

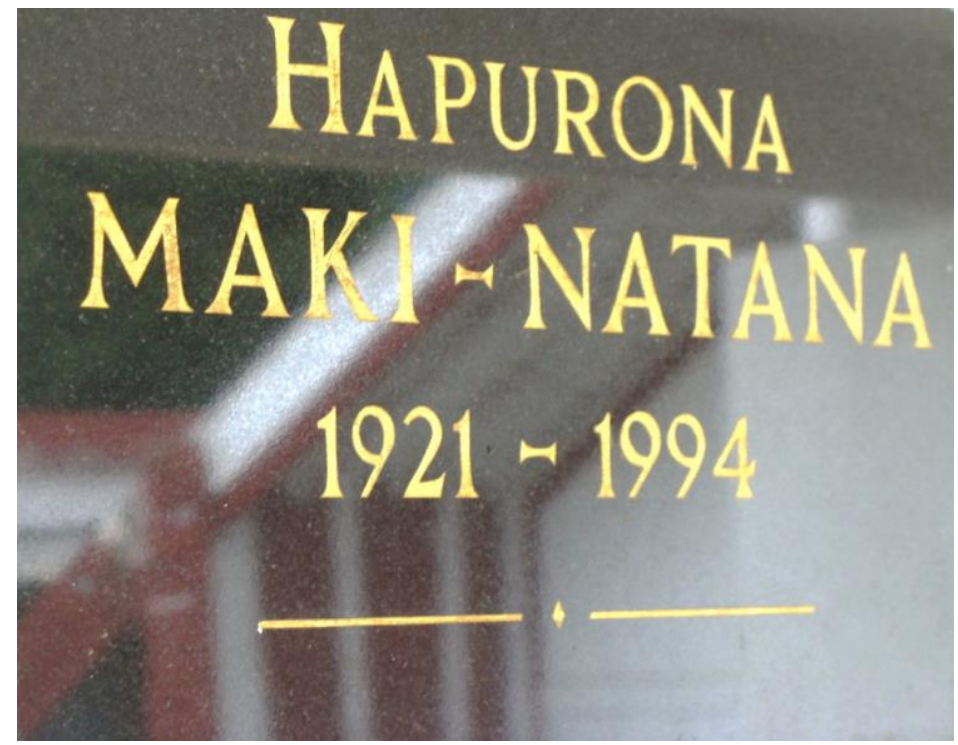

(B. Rangiwai, personal collection)

Hāpurona's mother was Rangimaewa Fitzgerald, granddaughter of Peraniko Tahawai. Her father, Edward Fitzgerald, was amongst the first wave of Pākehā who moved to Murupara. According to Henry Tahawai Bird (1980), a rangatira of Ngāti Manawa and descendent of Peraniko: "Mr Fitzgerald married Riripeti, daughter of Peraniko and from this union they had two daughters, - the elder one Rangimaewa married Mr. Maki Natana of Waiohau and had many children, the eldest [Hāpurona] Ted Maki being their leader" (p. 26). Koro Hāpurona and his cousin, Koro Wiremu McCauley (1918-1995), both direct descendants of Koura, were the last of their generation 
who vigorously and unapologetically defended their Patuheuheutanga. Both men are remembered as rangatira within their respective whānau, hapū and iwi.

Koro Hāpurona passed away when I was 14 years old. Koro was always very kind to me. He had many children, grandchildren, and what seemed like "countless" greatgrandchildren. His eldest daughter was my grandmother; and her eldest daughter is my mother (see Figure 1). I am Koro Hāpurona's eldest great-grandchild. He was a major influence in my life, and in the lives of our entire whānau. Christmas gatherings were almost always centred around him and held at his home in Murupara. He was a central figure in all of our lives, he was our champion and leader. Koro Hāpurona determined how things would be; his word was law for us. He decided where our loved ones would be buried; he went to other rohe and uplifted deceased relatives - unchallenged by the people of those rohe as he was fierce and authoritative - and brought them back to our marae at Waiōhau. He was the person that my grandmother would turn to for advice. My grandmother helped to care for Koro Hāpurona before he passed away. More than two decades after he passed away my grandmother still went to the urupā to cry for him, to off-load her worries, and to seek advice from him; that was how important he was to her and to us all. His influence in my life has significantly shaped who I am, my practice as a researcher, and indeed the way in which I carried out my doctoral research. My experiences growing up around him, and continuing to recognise his legacy in our whānau are examples of my inescapable hereditary entanglement in my $\mathrm{PhD}$ project. 


\section{Image 5: Koro Hāpurona Maki Nātana and Nanny Pare Koekoeā Rikiriki}

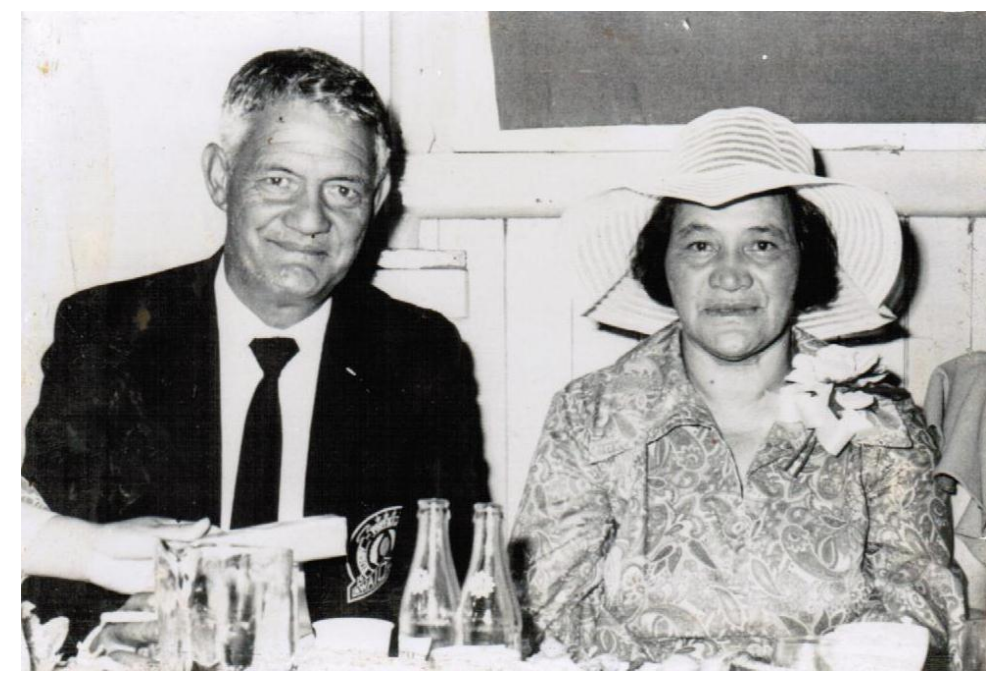

(Rangiwai whānau private collection)

Koro Hāpurona was married to Nanny Pare Koekoeā Rikiriki, granddaughter of Mēhaka Tokopounamu. I remember that Nanny Pare, spoke mostly in te reo Māori and was not overly fluent in English. She had a sitting room with photographs all over the walls. One photograph I recollect quite distinctly was of my great-grandmother's brother, Private Roihi Rikiriki of the 28 $8^{\text {th }}$ Māori Battalion, who died 18 February 1944 in Italy (Roll of Honour, Auckland Province, 1939-1945, Auckland Museum; Second New Zealand Expeditionary Force, Nominal Roll No. 5, 1942). Some of the other memories I have of my greatgrandmother include drinking tea from tin mugs; eating off a newspaper-covered table; coloured feather dusters in vases; cluttered photographs on the walls; scarves worn over her head; jam tarts made with wild pork fat and homemade jam; blackberry nip mixed with lemonade; and seeing her sweep out the house with mānuka branches. 
My whakapapa and genealogical locatedness, combined with my life experiences greatly influenced the way in which both my master's and $\mathrm{PhD}$ research was carried out. In my master's thesis I acknowledged my great-grandparents, Koro Hāpurona and Nanny Pare in the following way:

I acknowledge the complex matrix which is my whakapapa, all those who have gone before me, and all those yet to come. Special greetings go to my koroua Hāpurona Maki Nātana whose legacy of leadership for our family has inspired me to engage in this work and to my kuia Pare Koekoeā Rikiriki, whose meek and humble nature is remembered by many (Rangiwai, 2010, p. ii).

Furthermore, I dedicated my $\mathrm{PhD}$ thesis to my greatgrandparents and made the following acknowledgement:

This work is dedicated to my maternal greatgrandparents Koro Hāpurona Maki Nātana (19211994) and Nanny Pare Koekoeā Rikiriki (1918 1990). Koro and Nan you will always be missed. I ask you to continue to watch over the whannau and inspire us to maintain our Patuheuheutanga. Arohanui, your mokopuna tuarua (Rangiwai, 2015, p. ii).

My maternal grandmother ("Nan"), Rēpora Marion Brown (1940-2017), also known as Whakatangi Rikiriki, had a tremendous influence on my identity and thinking and always encouraged me to seek out education. Indeed, being the eldest daughter of Koro Hāpurona and Nanny Pare, my grandmother shared with me many of the stories from her life, as well as those passed down from her parents, which have played a major part in shaping and framing my practice as a researcher. My Nan was the single most powerful influence in my life. From the day that I was born, she has been there for me in every way. She 
essentially raised me and I owe her everything. In my $\mathrm{PhD}$ thesis, I made the following acknowledgement to her:

\begin{abstract}
Most importantly, I want to thank my grandmother, Rēpora Brown (also known as Whakatangi Rikiriki). Nan you have always been there for me throughout my life. During my $\mathrm{PhD}$ journey you always encouraged me along the way. Thank you for the support, for the cooking, for the warm rewwena bread, and most of all for ALWAYS believing in my ability to complete my master's and doctoral degrees. I dedicated this thesis to your parents, but this thesis is also dedicated to you, their eldest daughter, and to the generations of our whānau and hapu yet to come. Thank you Nan. All my love, now and forever (Rangiwai, 2015, p. xii).
\end{abstract}

Nan was a practicing Ringatū - the religion of Te Kooti Arikirangi Te Turuki. Her Ringatū faith, and my experiences being raised around the practices of that faith, have influenced the way in which I viewed, interpreted and analysed Te Kooti's prophecy, Te Umutaoroa, in my doctoral work. Nan was a woman of faith. She prayed unceasingly for her whānau. Whenever we travelled away from home, she blessed my sister and I with water from the Whirinaki River - which she kept in a re-used fizzy drink bottle - and made the sign of the cross upon our foreheads (the signing of the cross was perhaps an influence that came from the Catholic side of her family). Whenever we were ill, Nan would bless us with water and karakia. In the case of my uncle, who became quite ill and disturbed, she took him to a Ringatū tohunga for karakia.

One of the major events in Nan's life that challenged her faith was in 1999, when Nan became extremely ill. She had been admitted to Rotorua Hospital. She was jaundiced. The doctors explained that she was acutely and gravely ill with liver disease and needed to be transferred to Auckland Hospital and would need a liver transplant. Whānau gathered in their droves and filed into her intensive care room to say goodbye. More than 45 
whānau members lined the hallways and the patient lounge. The staff allowed as many of us as could fit into the room; the staff would have known just how critical the situation was and so allowed whānau to flood the space.

Transported by helicopter to Auckland Hospital, the prospects were slim. The colour of her skin resembled that of a banana. She was in a state of delirium, in and out of consciousness. The doctors informed us that she was placed on a waiting list for a liver transplant, but that if a liver was not found within a certain, and short, timeframe, she would die. This news was of course devastating for our whānau. Nevertheless, being quite practical, we also prepared for the worst; in fact, we brought with us appropriate burial clothing.

At the eleventh hour, we received word that a suitable liver had been found - obviously at the cost of tragedy for another family. Before she went into surgery, we gathered for karakia. Nan was able to begin the Lord's Prayer in Māori, but it was my mother that finished the prayer for her. Nan died on the table but was successfully resuscitated. She recounted to us her experience of seeing a bright light - a light that enveloped her entire being, a light of love where she felt the presence of whānau and a sense of divine peace. She heard a voice say: "It is not your time, yet".

Nan's recovery was very long. She spent weeks and months at Auckland Hospital, supported by whānau. And for the remainder of her life, she would spend countless days and weeks in and out of hospital for a plethora of medial issues related to her liver. Nan was a woman of complete faith. She believed in God with every part of her being. She gave thanks and praise to the Lord for saving her life and giving her more time with her whānau and especially her mokopuna. Nan taught me that karakia is crucial in life. She prayed morning and night for the protection and success of her mokopuna.

Every significant event in Nan's life has been an important event in my life (at least since 1980 when I was born) and thus has shaped my perspective in terms of my research and research practice. The importance of faith and karakia were critical to my doctoral studies. I ensured that karakia was 
performed each day before I began writing, imploring divine protection and influence in all things. In combination with other prayers and sometimes even various forms of meditation, I would recite:

I runga $\mathrm{i}$ te ingoa o te Matua, me te Tama, me te Wairua Tapu. Āmene.

He hōnore, he korōria kit e Atua, he maungārongo ki te whenua, he whakaaro pai ki ngā tāngata katoa. Korōria ki to ingoa tapu. Âmene.

Recalling every experience in Nan's life that shaped my perspective is beyond the scope of this current paper. However, in the very near future, research will be done that will include a thorough autoethnographic account of just how much my grandmother has influenced and shaped who I am and how I see things, especially in terms of the development of my personal theology. At the time of writing this article, I was enrolled in a second $\mathrm{PhD}$ which is an exploration of syncretism in Māori theology; this piece of research is written from the perspective of my personal theology, a theology that has been considerably shaped by Nan.

Nan being a central figure in my life, my whakapapa to her and to her ancestors, and the direct genealogical connection to the topic of Patuheuheu hapu land loss and the advent of Te Kooti's Te Umutaoroa prophecy, are undeniable indicators of intense hereditary entanglement. Sadly, Nan passed away on 1 December 2017. Her liver transplant gave her so many more years to enjoy her mokopuna and if he were not for her encouragement and support, I may never have engaged with the academic space. She lay at her home in Murupara for one night. The next morning she lay for an hour at Rangitahi marae, Murupara, the home base of Ngāti Hui - a hapū of Ngāti Manawa, at the request of $\mathrm{Mr}$ Pem Bird QSM. Pembroke Peraniko Bird is a descendant of Peraniko (see Figure 1) through his first wife; and Nan is a descendant of Peraniko through his second wife. Mr Bird's request was based on close whakapapa as Peraniko (as explained previously in this work) was the ariki 
of Ngāti Manawa. Nan was transported to Patuheuheu marae in Waiohau for the remainder of her tangihanga, and interred at the urupā in Waiōhau at the feet of her father, Hāpurona Maki Nātana. Nan's death has been one of the most tragic moments of my life. However, as Māori, we know there to be another world, a world of wairua, and that she is always with me $\bar{a}-$ wairua. Moe mai e kui, moe mai rā.

In addition to the people who have influenced my Patuheuheu perspective, the activities, rituals and histories that surround Patuheuheu marae, Waiōhau, and more specifically Tama-ki-Hikurangi wharenui, to which I am hereditarily entangled, have been impacted upon my thinking and perspective as a person as a researcher. Tama-ki-Hikurangi is "...a meeting-house built for Te Kooti at Te Houhi (near Galatea) ${ }^{9}$ by the Patuheuheu people, a hapu of Tuhoe" (Binney, 1995, caption, plate 2; Neich, 1993). It is a focal point of the community and a constant reminder to me of Patuheuheu history, land loss and survival. I have fond childhood memories of playing 'tiggy' (tag) on the grassed area or marae ātea in front of the wharenui and naughtily jumping on the mattresses inside.

9 There are other claims that suggest that the wharenui first stood at Te Kowhai in the Horomanga area before being moved to Te Houhi. 


\section{Image 6: Tama-ki-Hikurangi wharenui, 2010, Patuheuheu marae, Waiōhau}

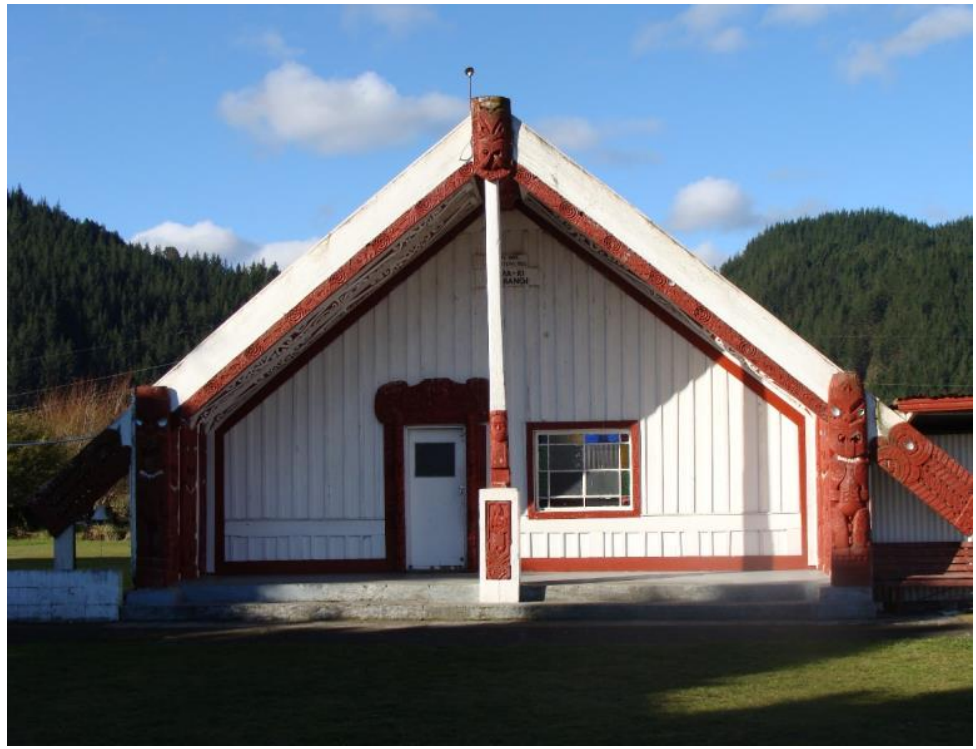

(B. Rangiwai, personal collection)

For me, the wharenui remains as an ever-intriguing source of influence and information. In my master's thesis, I described Tama-ki-Hikurangi in the following way:

The carvings, with their 'grimacing' expressions tongues extended and teeth showing - and deeply grooved body patterns; the painted poupou in green, white, red and black; the brass cross encased in a wood and glass display box, perched high on the back wall; the faded picture of Jesus Christ, praying for the sins of mankind. Then there are the curiously painted visual 'narratives' on some of the rafters: the ominous image of a white man with a facial tattoo; another hunting birds, 
probably kererū in a tree; 10 a brown man with a white head piercing his human victim with a spear, lifting him high in the air; ${ }^{11}$ a 'little man' cutting down what looks to be a ponga tree; and yet other more 'Christian' images of baptisms and blessings. The red, black and white kowhaiwhai patterns hypnotically 'snake' their way across the wharenui's 'spine', while the poutokomanawa, Papanui, stands majestically as his chiefly gaze surveys all those who enter. There are photographs cluttered and clustered on the walls - the amount of photographs suggesting that this wharenui has a long history - watching over those who come to meet and rest. When I enter, my eyes are automatically drawn to the pictures I have been told stories about through the years. My grandmother told me: "this is a picture of my kuia Rangimaewa Fitzgerald when she was young; she was half Irish and a staunch Catholic; she used to fast a lot and ate fish on Fridays" and "this is my koroua Maki Nātana, he married Rangimaewa" (Rangiwai, 2010, p. 3-4).

10 "[T]he sustenance of life for Tuhoe: snaring birds" (Binney, 1995, caption, plate 2 ).

11 According to Binney (1995) this motif “...shows the act of bayoneting, following Pslam 63, and this painting is understood to refer to the killings at Mohaka in 1869" (caption, plate 2) during the fighting with Te Kooti "where people were caught sleeping and all were killed, even babies, who were thrown up in the air and bayoneted" (Neich, 1993, p. 261). Consistently, Brown (2009) states: "[a] bayoneting scene on one of the heke in Tama-kiHikurangi referred to Te Kooti's 1869 raid on Mohaka, where he took revenge on his Pākehā enemies" (p. 64). 
Image 7: Bird snaring scene on one of the heke inside Tama-ki-Hikurangi wharenui, Patuheuheu marae, Waiōhau

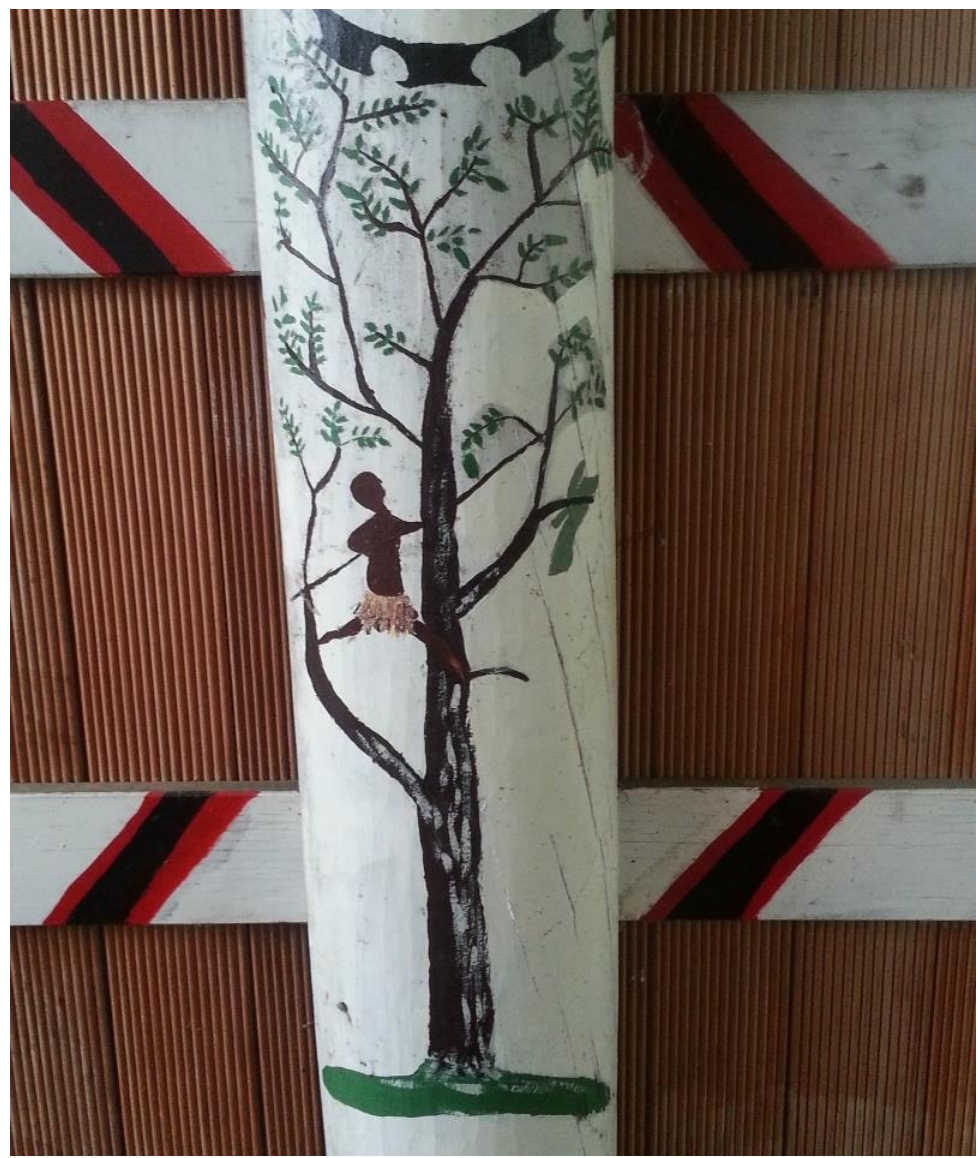

(B. Rangiwai, personal collection)

Of the many wharenui to which I am connected by genealogy, Tama-ki-Hikurangi is the most familiar. This history of this wharenui is embedded in Patuheuheu hearts and minds. It is a history of loss and tragedy, but one where hope of restitution remains. The wharenui is the embodiment of that history and 
has been an anchor point for both my master's and doctoral research. For me, the wharenui continues to raise a number of questions around my Patuheuheu identity and the significance of this identity in carrying out my research and as a research practitioner.

In 1994, when I was a fourth-form high school student at Rangitahi College, Murupara, during 'Māori Week'12 I joined a group of students who elected to take a history tour with a local kaumātua. This elderly man took the group out to Galatea and recalled the story of the 'Waiōhau Fraud'. He informed us that Patuheuheu did not always live in Waiohau, that they had once lived on the much more fertile lands of Te Houhi, located in present-day Galatea. The elder told us of a story where the land was taken away from its rightful owners, where the wharenui was kept and desecrated by the new Pākehā owner and where the remains of the dead had to be left behind.

The kaumātua told us that the chiefs of the village, Wi Pātene Tarahanga and Mēhaka Tokopounamu (see Figure 1) fought for the land but that the colonial system proved too difficult to overcome. We were told that Te Houhi was sold from under Patuheuheu hapū by a man called Harry Burt; this was a man who spoke te reo Māori and had been trusted by the people. The elder informed us that as a consequence of the loss of Te Houhi, Te Kooti gifted a prophecy that promised restoration. The kaumātua spoke of a prophecy called Te Umutaoroa which contained eight umu stones, each with a mauri and the power to positively transform the future for the descendants of those who were affected by Burt's actions in the nineteenth century.

For Māori, losing land is a disastrous event that negatively affects identity. Cheater and Hopa (1997) and Durie (1998) note that whenua is an imperative aspect of Māori identity.

12 When I attended Rangitahi College in Murupara, during one week each year students, teachers and the community participated in Māori Week. During Māori Week there would be a focus on local history, te reo Māori, waiata, haka, raranga, and mahi kai, underpinned by Ngāti-Manawatanga (Ngāti Manawa culture, customs, practices and beliefs). 
According to Durie (1998), Māori identities are based not only on positive connections to land, but also on collective experiences around land, such as raupatu and other forms of land loss. As a descendant of the victims of land loss, I am forever connected by genealogy to Te Houhi, despite the land now being owned by Pākehā farmers. It is here at the crossroads of whakapapa, whenua and history that I stand, hereditarily entangled in the research as part of my 'lived experience' and reality. According to Mkhize (2004) "lived experience' refers to real life, as opposed to laboratory or hypothetical, experiences" (p. 28). These all-encompassing lived experiences and links to whakapapa, whenua and history, mean that it was impossible for me be disentangled from the genealogical context of my doctoral research.

This article has described the term hereditary entanglement and has contextualised this term within the context of doctoral research that I completed at Auckland University of Technology in 2015. It has been argued that the first time that the notion of hereditary entanglement in relation to whakapapa and genealogical locatedness in Māori research occurred in my doctoral research. The term hereditary entanglement is, now used, here in this published work. Kaupapa Māori theory says that one's connection to the Māori research context must be made explicit and should be declared up front. However, hereditary entanglement suggests that while one's identity and connection to the research should be made clear, in cases where one's whakapapa is directly linked to a research kaupapa, and/or where one is genealogically located in the research context historically or otherwise, then it is in fact impossible not to be hereditarily entangled in the research context, and that it might be useful to use this stronger terminology to declare one's interests in the research. 


\section{References}

Archives New Zealand (2010). Nāku, nā Tūhoe. Wellington, New Zealand: Author.

Auckland Museum (n.d.). Roll of honour, Auckland province, 1939-1945. MSS 93/139, Auckland Museum, Auckland, New Zealand.

Best, E. (1902). Notes on the art of war as conducted by the Maori of New Zealand, with accounts of various customs, rites, superstitions, pertaining to war, as practised and believed in by the ancient Maori. Journal of the Polynesian Society, 11(3), 127-162.

Binney, J. (1995). Redemption songs: A life of Te Kooti Arikirangi Te Turuki. Auckland, New Zealand: University Press and Bridget Williams.

Binney, J. (2001). Te Umutaoroa: The earth oven of long cooking. In A. Sharp \& P. McHugh (Eds.), Histories, power and loss: Uses of the past - a New Zealand commentary (pp. 146-64). Wellington, New Zealand: Bridget Williams.

Binney, J. (2007). When the white kawau flies. In J. Lutz (Ed.), Myth and memory: Stories of indigenous-European contact (pp. 140-159). Vancouver, Canada: UBC Press.

Binney, J. (2008). Untold lives: When the elders tell their stories. Dunedin, New Zealand: Hocken Collections.

Binney, J. (2009). Encircled lands: Te Urewera, 1820-1921. Wellington, New Zealand: Bridget Williams.

Binney, J. (2010). Stories without end: Essays 1975-2010. Wellington, New Zealand: Bridget Williams.

Bird, H. T. (1980). Kuranui o Ngati Manawa. Rotorua, New Zealand: Author.

Boast, R. (2008). Buying the land, selling the land. Wellington, New Zealand: Victoria University Press. 
Brown, D. (2009). Māori architecture: From fale to wharenui and beyond. Auckland, New Zealand: Penguin.

Cheater, A. \& Hopa, N. (1997). Representing identity. In A. James, J. Hockey \& A. Dawson (Eds.), After writing culture: Epistemology and praxis in contemporary anthropology (pp. 208-23). Oxon, United Kingdom: Routledge.

Crosby, R. (2004). Gilbert Mair: Te Kooti's nemesis. Auckland, New Zealand: Reed.

Doherty, W. (1995). Traditional history relating to Matahina $C$ and C1 and Patuheuheu and Ngati Haka. Murupara, New Zealand: Te Runanganui o Te Ika Whenua.

Durie, M. (1998). Te mana, te kāwanatanga: The politics of Māori selfdetermination. Melbourne, Australia: Oxford University Press.

Finlayson, C. (18 December, 2009). Speech for the launch of Dame Judith Binney's 'Encircled Lands' at Parliament. Launch of 'Encircled Lands', New Zealand Government, Wellington, New Zealand. Retrieved from: http://www.beehive.govt.nz/node/38310

Mair, G. (1923). Reminiscences and Maori stories. Auckland, New Zealand: Brett Printing and Publishing Company.

McBurney, P. (2004). Ngati Manawa and the Crown (Report). Wellington , New Zealand: Crown Forestry Rental Trust.

Mead, H. M. \& Phillis, O. E. (1982). The abundant earth - Te one matua: The centennial of Ruataupare at Kokohinau marae. Te Teko, New Zealand: Te Komiti Maori o Kokohinau.

Milroy, W. (1994). Tamarau Waiari 1835-1904. In Dictionary of New Zealand biography (Vol. 2, 1870-1900, pp. 499-500). Wellington, New Zealand: Department of Internal Affairs, Bridget Williams.

Mkhize, N. (2004). Psychology: An African perspective. In D. Hook, N. Mkhize, P. Kiguwa, A. Collins, E. Burman \& I. Parker (Eds.), Introduction to critical psychology (pp. 25-52). Cape Town, Republic of South Africa: UCT Press.

Neich, R. (1993). Painted histories: Early Maori figurative painting. Auckland, New Zealand: Auckland University Press. 
Paul, G. M. (1995). Te Houhi and Waiohau 1B (Wai 212). Murupara, New Zealand: Te Runanganui o Te Ika Whenua.

Rangiwai, B. (2010). The effects of racism on Māori land loss: Colonising discourses for Te Patuheuheu and Ngāti Haka. Unpublished master's thesis, Te Whare Wānanga o Awanuiārangi, Whakatāne, New Zealand.

Rangiwai, B. (2015), Ko au ko Te Umutaoroa, ko Te Umutaoroa ko au: Toward a Patuheuheu hapū development model. Unpublished doctoral thesis, Auckland University of Technology, Auckland, New Zealand.

Second New Zealand Expeditionary Force Nominal Roll No. 5 (1942). Embarkations from 1st July, 1941 to 30 September, 1941. Wellington, New Zealand: Blundell Bros. Limited Printers.

Seddon family (n.d.). Deputation of Urewera chiefs to Richard John Seddon, at the Ministerial Residence, Molesworth Street, Wellington. Wellington, New Zealand: Alexander Turnbull Library, Wellington, New Zealand. (1/2-098554-F)

Waaka, T. (2001). Who validates a hapuu. Paper presented at New Zealand Association for Research in Education Conference. Retrieved from: http://www.nzabe.ac.nz/conferences/2001/pdf/03_friday_pm/C herylStephenssymp2-BD3.pdf

Waitangi Tribunal (2002). The Ngāti Awa settlement cross-claims report. Wellington, New Zealand: Author. 